\title{
LOW-CARBON ECONOMY IN THE MUNICIPALITY OF SUCHA BESKIDZKA
}

\author{
Agnieszka Petryk ${ }^{1}$ \\ 1 Department of Economy and Public Administration, Cracow University of Economics, Rakowicka 27, \\ 31-510 Kraków, Poland, e-mail: agnieszka.petryk@uek.krakow.pl
}

Received: 2017.05.16

Accepted: 2017.08.01

Published: 2017.09.01

\begin{abstract}
The paper presents an analysis of proecological activities undertaken by the management of the Municipality of Sucha Beskidzka. The activities aimed at limiting the low emission and, consequently, at introducing low-carbon economy in the area. The municipality is determined to phase out the burning of fossil fuels and replace it with cleaner and safer energy sources, which is supposed to contribute to the reduction of $\mathrm{PM}_{10}$ and $\mathrm{PM}_{2.5}$ particulate matter emissions and air pollution. In order to combat the problem of low emission, the municipality developed a Low Emission Reduction Programme (LERP) in 2014. The town of Sucha Beskidzka also participates in the Life Program and as part of it, an eco-adviser has been employed. The implementation of LERP has been reflected in the Area Development Plan of the municipality. The actions taken by the local government to protect air are effective. The Municipality of Sucha Beskidzka was one of the two municipalities in the entire Malopolska province which fully implemented the Air Protection Program for the years 2013-2015. In the years 2014-2016 as many as 103 buildings underwent thermo-modernization. In 2016 RES (solar installations) were installed in 402 detached houses. In the period 2014-2016, 1055 coal boilers were dismantled and replaced by gas boilers or class 5 boilers.
\end{abstract}

Keywords: low emission, low-carbon economy, boilers, air pollution, particulate matter

\section{INTRODUCTION}

Reducing the incidence as well as environmental and socio-economic impacts of low emission and the developing low-carbon economy in line with the assumptions of the sustainable development of the country, are the fundamental aim of pro-ecological activities proposed in the National Programme for the Development of Low-Carbon Economy [Jankiewicz 2014]. These activities include the use of renewable energy sources in the energy economy, the improvement of energy efficiency by optimising the fuel combustion process and the implementation of modern low-emission technologies (e.g. cogeneration and trigeneration systems), also as part of the modernisation of the existing transmission lines [Gostomczyk 2014]. In low carbon economy, replacement of fossil fuels with ecological ones, i.e. with clean energy which is safe for the human health and the environment is the ultimate goal [Gostomczyk 2014].
The justification for undertaking a wide range of environmental actions in the context of low-carbon economy is the widely recognized fact that low emission became an important climate factor for urbanized and industrialized areas, especially those of large cities [Skrzypski, Papiernik, 2006; Lewińska , et al. 1990]. Generally, in highly urbanized areas, low emission sources include industrial and transportation pollution as well as pollution originating from heating networks and fossil fuel combustion [Kaczmarczyk et al. 2015]. The sources of low-carbon pollutants can be local or point-based and can take the form of inflow emission [Lewińska et al.1990]. Coal combustion is associated with low carbon emission of carbon monoxide, nitrogen oxides and particulate matter, and the result of incomplete combustion is the emission of (aromatic, paraffinic, oleic, polycyclic) hydrocarbons [Skrzypski, Papiernik 2006]. The type and structure of low-emission air pollutants are multifactorial 
(Table 1); however, secondary pollutants might be more toxic than the primary pollutants [Skrzypski, Papiernik 2006].

According to the World Bank report [2011], which predicts the development of low-emission economy in Poland, the energy sector accounts for almost half of the value of low emission in the Polish economy. The currently exploited technologies will allow to reduce the greenhouse gases emissions by one third by 2030. The report concludes that Poland can successfully transform its economy into low-carbon economy, as it made a positive shift from a centrally planned economy to the market economy. This transformation will be one of the factors accelerating the economic growth by 2030, although in 2020 its costs will be the highest.

In 2015, the European Commission referred negatively to the methods of reducing low emissions in terms of legislative and administrative solutions which Poland applied, considering them insufficient. Excessively high levels of particulate matter in the air, significantly exceeding the limit values in the European Union, resulted in the initiation of proceedings against Poland before the Court of Justice in Luxembourg by the European Commission in December 2015 [APP 2017].

A set of corrective actions related to the high level of low emission in the Małopolska Province was elaborated in the Air Protection Program for the Małopolska Province in 2013, which was announced in 2013 and then updated in January 2017. The deadline for its implementation is the year 2023. A significant reduction in the number of low emission surface sources was indicated as the overriding goal of the Program. In the years 2013-2015 one of the most effective corrective actions was the liquidation of old appliances exploiting solid fuels (boilers and stoves) (Table 2) [APP 2017].

In the years 2013-2015, the highest growth of investments limiting surface emissions in the Małopolska Province was recorded in the renewable energy sector (1292\%). In 2015, the number of thermo-modernized buildings decreased, compared to 2013; however, the largest number of investments were made in this area in 2014. In the analyzed two-year period, the slight growth referred to the investments connected to the modernisation of the heating network (Table 2).

In the years 2013-2015, the share of lowcarbon solid fuel boilers in the general distribution of sources increased considerably, replacing the coal boilers as part of the implementation of the Air Protection Program (Table 3). During the considered period, the share of heating networks and electric heating as alternative solutions to coal boilers was considerably reduced. A slight increase in the percentage share of gas installations in the withdrawal of facilities exploiting solid fuel (coal boilers) was noted in the analysed two-year period.

Despite the pro-ecological actions successively undertaken as part of the implementation of the Air Protection Program, coal remained the main source of heat in the Małopolska Province

Table 1. Factors determining the type and structure of pollutants in low emission

\begin{tabular}{|l|c|c|c|l|}
\hline \multicolumn{1}{|c|}{ Energy demand } & Energy carriers & Fuel quality & $\begin{array}{c}\text { Method of obtaining } \\
\text { energy }\end{array}$ & \multicolumn{1}{|c|}{ Protective infrastructure } \\
\hline The size of the city & solid fuels & calorific value & stove & $\begin{array}{l}\text { methods of purifying waste } \\
\text { gases }\end{array}$ \\
\hline The area of the city & gaseous fuel & sulphation & grate boiler & gas purification facilities \\
\hline $\begin{array}{l}\text { Location of the city in rela- } \\
\text { tion to climatic zones }\end{array}$ & liquid fuels & ashing & dust boiler & gas purification installations \\
\hline $\begin{array}{l}\text { Industrial function deve- } \\
\text { lopment }\end{array}$ & $\begin{array}{c}\text { renewable sources } \\
\text { of energy }\end{array}$ & admixtures & fluidized bed boiler & \\
\hline & others & & car engine & \\
\hline
\end{tabular}

Source: Own study based on the basis of Skrzypski, Papiernik [2006].

Table 2. Number of investments limiting surface emissions in the Małopolska Province in the years 2013-2015

\begin{tabular}{|c|c|c|c|c|c|}
\hline Years analysed & $\begin{array}{c}\text { Solid fuel boilers } \\
\text { withdrawal }\end{array}$ & $\begin{array}{c}\text { Thermomodernization } \\
\text { of buildings }\end{array}$ & $\begin{array}{c}\text { Renewable sourc- } \\
\text { es of energy }\end{array}$ & $\begin{array}{c}\text { Modernisation of } \\
\text { heating networks }\end{array}$ & Others \\
\hline 2013 & 2607 & 716 & 407 & 21 & 21 \\
\hline 2014 & 3100 & 925 & 4041 & 27 & 34 \\
\hline 2015 & 4446 & 667 & 5260 & 30 & 43 \\
\hline
\end{tabular}

Source: Own study based on the Air Protection Program for the Małopolska Province 
Table 3. Share of types of heating sources which replaced coal boilers in the Małopolska Province in years 2013-2015

\begin{tabular}{|c|c|c|c|c|}
\hline Years analysed & Gas heating & Heating network & Low-emission solid fuel boilers & Electric heating \\
\hline 2013 & $60 \%$ & $30 \%$ & $1 \%$ & $9 \%$ \\
\hline 2014 & $68 \%$ & $23 \%$ & $4 \%$ & $5 \%$ \\
\hline 2015 & $65 \%$ & $20 \%$ & $11 \%$ & $4 \%$ \\
\hline
\end{tabular}

Source: Own study based on the Air Protection Program for the Małopolska Province

in 2015. The percentage share of sources covering the heating needs of the inhabitants of the Małopolska Province in 2015 was as follows: $65 \%$ - coal, approx. $23 \%$ - gas, $8 \%$ - heating network, $2 \%$ - wood, $1 \%$ - fuel oil [APP 2017].

The data obtained from the inventory carried out in 10 communities of the Małopolska Province indicated that in 2015, $73 \%$ of single-family houses used solid fuels. Gas was exploited by nearly $40 \%$ of households. The inventory results confirmed that in many single-family buildings, a dual heating system that combines solid fuels with gaseous fuels, electric heating or RES was used. Boilers with manual loading prevailed in households. Modern automatic boilers were 6 times less frequent than those with manual loading [APP 2017].

In the multifaceted analysis of the low emission problem in the Małopolska Province, it should be taken into account that specific climatic and topographic conditions and the influx of air pollution from the heavily industrialised Silesian Province are important factors contributing considerably to low emission in the province [Environmental Status Report 2013-2015].

\section{LOW EMISSION IN THE MUNICIPALITY OF SUCHA BESKIDZKA}

The town of Sucha Beskidzka is the capital of the municipality of Sucha Beskidzka as well as the Suski County. The municipality is located in the south-western part of the Malopolska Province in a typical mountainous area, where three mountain ranges of the Beskidy, i.e. Makowski, Żywiecki and Mały join. Fogs and strong south and southwestern winds are the main unfavourable climatic factors of this region [Study of Conditions 2016].

No heavy industry was developed in the municipality. The trade and services sector with a large number of small and medium-sized enterprises is well developed. Family businesses are one of the main sources of livelihood for the local residents [Local Development Plan 2004-2013].
Since 2014, the Low Emission Reduction Program has been being implemented in the municipality. A predominant number of households use coal boilers, where culm coal and coal of low quality are mostly burnt. In addition to traffic pollution, combustion chimneys are also a significant source of low emission. In 2011, an automatic air monitoring station carrying out systematic pollutant measurements was open in the municipality [LERP 2014].

In 2014, the average annual concentration of $\mathrm{PM}_{10}$ in the municipality amounted to $46.9[\mu \mathrm{g} /$ $\mathrm{m} 3$ ], thus exceeding the permissible concentrations according to the CIEP (Chief Inspectorate of Environmental Protection) recommendations (Table 4). The reduction of air pollution is possible through the elimination of coal boilers. In 2014, 391 coal boilers were replaced, and in 2016 as many as 423 boilers were substituted with class 5 boilers. The analysis of the declarations submitted by residents in years 2014-2016 shows that as many as 491 households declared the replacement of coal boilers for gas fuelled boilers, 378 households for class 5boilers and 11 households for pellets.

In 2016, there were 2786 households in the Sucha Beskidzka municipality (Table 5).

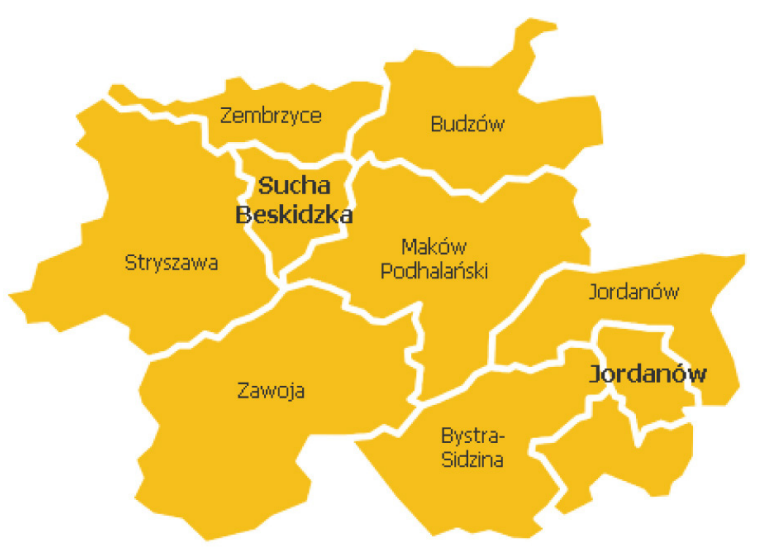

Figure 1 Location of Sucha Beskidzka against the Suski County

Source: www.google.pl 
Table 4. Annual mean values of pollutants in the air in the municipality of Sucha Beskidzka in 2014

\begin{tabular}{|c|c|c|c|c|c|}
\hline \multirow[b]{2}{*}{ Year 2014} & $\mathrm{SO}_{2}$ & $\mathrm{NO}_{2}$ & $\mathrm{CO}$ & PM10 & PM2.5 \\
\hline & Sulphur dioxide & $\begin{array}{l}\text { Nitrogen } \\
\text { dioxide }\end{array}$ & $\begin{array}{c}\text { Carbon } \\
\text { monoxide }\end{array}$ & $\begin{array}{c}\text { Particulate matter } \\
\text { PM10 }\end{array}$ & $\begin{array}{l}\text { Particulate matter } \\
\text { PM2.5 }\end{array}$ \\
\hline \multirow{2}{*}{$\begin{array}{l}\text { The mean annual values } \\
\text { of pollutants in the air }\end{array}$} & {$\left[\mu \mathrm{g} / \mathrm{m}^{3}\right]$} & {$\left[\mu \mathrm{g} / \mathrm{m}^{3}\right]$} & {$\left[\mu \mathrm{g} / \mathrm{m}^{3}\right]$} & {$\left[\mu \mathrm{g} / \mathrm{m}^{3}\right]$} & {$\left[\mu \mathrm{g} / \mathrm{m}^{3}\right]$} \\
\hline & 20.2 & 20.2 & no data & 46.9 & no data \\
\hline $\begin{array}{l}\text { The permissible concen- } \\
\text { tration according to the } \\
\text { CIEP }\end{array}$ & $\begin{array}{l}\text { measurement period } 24 \mathrm{~h} \\
125\end{array}$ & $\begin{array}{c}\text { calendar year } \\
40\end{array}$ & $\begin{array}{l}8 \text { hour } \\
10000\end{array}$ & $\begin{array}{l}\text { calendar year } \\
40\end{array}$ & $\begin{array}{l}\text { calendar year } \\
20\end{array}$ \\
\hline
\end{tabular}

No measure data for 2015, 2016.

Source: Own study based on the data from the Town Hall of Sucha Beskidzka December 2016

Table 5. Number of households (single and multi-family housing) in the municipality of Sucha Beskidzka in years 2014-2016

\begin{tabular}{|c|c|c|c|}
\hline Year analysed & 2014 & 2015 & 2016 \\
\hline Number of households & 2771 & 2779 & 2786 \\
\hline
\end{tabular}

Source: Own study based on the data from the Town Hall of Sucha Beskidzka

Among the main fuels, coal, gas, fuel oil or other sources were used.

According to the data of the Town Hall of Sucha Beskidzka in 2016, 1345 single-family and multi-family buildings were heated by coal (Table 6). In 2014, the number of coal boilers in the municipality amounted to 1776 . Only 143 households utilised a different power source. In 2014, only 782 buildings in the municipality were gas-heated in winter. In 2016, the number increased to 1237.

In 2014, the estimated fuel consumption for heating purposes in households amounted to: coal -5 769.00 Mg/year, fuel oil - $161938.00 \mathrm{l} /$ year. Hot water was acquired in 2400 single and multifamily buildings using combustion boilers. On the other hand, 402 households owned additional heat sources in the form of solar installations. In
2016, about 1800 households had boilers in good technical condition. In the area of the municipality the following amounts of coal were used for the purpose of heating multi-family buildings:

- in $2014-548510 \mathrm{~kg} /$ year coal

- in 2015 - $243000 \mathrm{~kg} /$ year coal

- in 2016 - $27000 \mathrm{~kg} / \mathrm{year}$ coal,

This enables to estimate the value of pollutant emissions to atmospheric air from multi-family housing (Table 7).

In the area of the municipality, there are numerous public utility buildings (Table 8) and factories (Table 9) which utilised different heating methods.

The actions taken as part of the LERP Program enabled the thermo-modernisation of 103 buildings in years 2014-2016 and the installation of

Table 6. Number of households including multi-family buildings in years 2014-2016 in the municipality of Sucha Beskidzka heated by coal, gas or fuel oil

\begin{tabular}{|c|c|c|c|c|}
\hline Year analysed & Coal & Gas & Fuel oil & Another type of fuel \\
\hline 2014 & 1776 & 782 & 61 & 152 \\
\hline 2015 & 1517 & 1057 & 61 & 144 \\
\hline 2016 & 1345 & 1237 & 61 & 143 \\
\hline
\end{tabular}

Source: Own study based on the data from the Town Hall of Sucha Beskidzka

Table 7. Number of pollutants in 2014-2016 emitted by multi-family buildings

\begin{tabular}{|c|c|c|c|c|c|}
\hline \multirow{2}{*}{ Year } & Total particulate matter & $\mathrm{SO}_{2}$ & $\mathrm{NOx}$ & $\mathrm{CO}$ & $\mathrm{CO}_{2}$ \\
\cline { 2 - 5 } & \multicolumn{5}{|c|}{$\mathrm{kg} /$ year } \\
\hline 2014 & 10888.0 & 17528.8 & 951.4 & 53020.0 & 960806.0 \\
\hline 2015 & 5090.0 & 8170.0 & 420.0 & 24970.0 & 432900.0 \\
\hline 2016 & 509.0 & 817.0 & 42.0 & 2497.0 & 43290.0 \\
\hline
\end{tabular}

Source: Own study based on the data from the Town Hall of Sucha Beskidzka 
RES (solar installations) in 402 buildings including single-family buildings, a Municipal Nursery School, a Water Treatment Station and a District Hospital. Actions taken to improve the air quality allowed for the replacement of 98 coal boilers for eco-coal fuelled boilers (Table 10) in the Sucha Beskidzka municipality in the years 2014-2016.

Thanks to the replacement of coal boilers with gas boilers in the municipality, $\mathrm{CO}^{2}$ emissions were reduced by $374204.3 \mathrm{~kg}$ year (2016), whereas particulate matter - by $5257.8 \mathrm{~kg} /$ year (2016) (Table 10).

\section{CONCLUSIONS}

- The pro-ecological activities carried out in the area of the LERP Program aim at improving the air quality and are supported by preventive and educational actions in nurseries and schools in the form of various actions, contests, happenings, etc.

- The City Guard representing the Municipality carries out regular inspections of home stoves. In the case of suspected incineration of municipal waste in coal boilers, the officers

Table 8. Inventory of public utility buildings in the municipality influencing low emission

\begin{tabular}{|c|c|c|}
\hline No. & Name of the institution & $\begin{array}{l}\text { Means of } \\
\text { heating }\end{array}$ \\
\hline 1. & District Hospital (Szpital Rejonowy) - ul. Szpitalna & Natural gas \\
\hline 2. & County District Office (Starostwo Powiatowe) - ul. Kościelna & Natural gas \\
\hline 3. & The Town Hall (Urząd Miasta) - ul. Mickiewicza & Natural gas \\
\hline 4. & District Court (Sąd Rejonowy) - ul. Mickiewicza & Natural gas \\
\hline 5. & District Employment Office (Powiatowy Urząd Pracy) - ul. B. Wildera & $\begin{array}{l}\text { Electrical } \\
\text { energy }\end{array}$ \\
\hline 6. & Tax office (Urząd Skarbowy) - ul. Mickiewicza & Fuel oil \\
\hline 7. & Social Insurance Office (Zakład Ubezpieczeń Społecznych) - ul. Rynek & $\begin{array}{l}\text { Electrical } \\
\text { energy }\end{array}$ \\
\hline 8. & Forestry Management in Sucha (Nadleśnictwo Sucha) - ul. Zamkowa & Natural gas \\
\hline 9. & District Police Station (Komenda Powiatowa Policji) - ul. Mickiewicza & Natural gas \\
\hline 10. & $\begin{array}{l}\text { District Command of Fire Department (Komenda Powiatowa Państwowej Straży Pożarnej) - ul. Ma- } \\
\text { kowska }\end{array}$ & Natural gas \\
\hline 11. & Volunteer Fire Department (Ochotnicza Straż Pożarna) - ul. Rynek & Natural gas \\
\hline 12. & District Prosecutor’s Office (Prokuratura Rejonowa) - ul. Piłsudskiego & Natural gas \\
\hline 13. & Buidling of Polish Post Office (Budynek Poczty Polskiej) & Fuel oil \\
\hline 14. & City Health Clinic (Miejska Przychodnia Zdrowia) - ul. Handlowa & Natural gas \\
\hline 15. & $\begin{array}{l}\text { Non-public health care facility (Niepubliczny Zakład Opieki Zdrowotnej MEDYK Sp. z o.o.) - ul. Mickie- } \\
\text { wicza }\end{array}$ & Natural gas \\
\hline 16. & Indoor Swimming Pool (Kryta Pływalnia) - ul. Zielona & Natural gas \\
\hline 17. & Library in Sucha Beskidzka (Biblioteka Suska) - ul. Piłsudskiego & Natural gas \\
\hline 18. & School of General Education (Zespół Szkół Ogólnokształcących) - ul. T. Semika & Natural gas \\
\hline 19. & W. Witos School Complex (Zespół Szkół im. W. Witosa) - ul. Spółdzielców & Natural gas \\
\hline 20. & W. Goetl School Complex (Zespół Szkół im. W. Goetla) - ul. Kościelna & Natural gas \\
\hline 21. & Muncipal Nursery School (Przedszkole Samorządowe) - ul. Mickiewicza & Natural gas \\
\hline 22. & $\begin{array}{l}\text { School Complex: Primary School No } 1 \text { and Junior High School (Zespół Szkół Szkoła Podstawowa nr } 1 \text { i } \\
\text { Gimnazjum) }\end{array}$ & Natural gas \\
\hline 23. & Primary School No 2 (Szkoła Podstawowa nr 2) - ul. Zasypnicka & Natural gas \\
\hline 24. & Branch of Primary School No 2 (Filia Szkoły Podstawowej nr 2) - ul. Błądzonka & Eco-coal \\
\hline 25. & Wyższa Szkoła Turystyki i Ekologii - ul. Zamkowa & Natural gas \\
\hline 26. & Vocational Training Centre (Zakład Doskonalenia Zawodowego)- ul. Rynek & Natural gas \\
\hline 27. & Municipal Daycare Centre (Miejska Świetlica Profilaktyczna)- ul. Handlowa & Natural gas \\
\hline 28. & Municipal Cultural Center (Miejski Ośrodek Kultury)- ul. Zamkowa & Natural gas \\
\hline 29. & Municipal Museum (Muzeum Miejskie) - ul. Zamkowa & Natural gas \\
\hline 30. & PKO S.A. Bank- ul. Mickiewicza & Fuel oil \\
\hline 31. & Cooperative Bank (Bank Spółdzielczy) - ul. Piłsudskiego & Fuel oil \\
\hline 32. & Train station (dworzec PKP) - ul. Mickiewicza & Coal \\
\hline
\end{tabular}

Source: Own study based on the data from the Town Hall of Sucha Beskidzka 
Table 9. Inventory of the largest factories and shopping and service buildings in the municipality influencing low emission

\begin{tabular}{|c|c|c|}
\hline No. & Name of the institution & $\begin{array}{c}\text { Means of } \\
\text { heating }\end{array}$ \\
\hline 1. & Fideltronik Company (Firma Fideltronik) - ul. Beniowskiego (approx. 1500 employees) & Natural gas \\
\hline 2. & Stolmarx Sc. Babiogórska Furniture Factory (Babiogórska Fabryka Mebli). Strączek - ul. Zamkowa & Biomass \\
\hline 3. & Confectionery and Bakery (Z.P. CIASTKARNIA-PIEKARNIA „URBAŃSCY”)- ul. Przemysłowa & Natural gas \\
\hline 4. & F.P.H.U. AKCES-PLAST - ul. Przemysłowa & Natural gas \\
\hline 5. & Water Treatment Station (Stacja Uzdatniania Wody) - ul. Role & Fuel oil \\
\hline 6. & Municipal Services Office (Zakład Komunalny) - ul. Wadowicka & Natural gas \\
\hline 7. & $\begin{array}{l}\text { Regional Waste Treatment Plant in Sucha Beskidzka (Regionalny Zakład Przetwarzania Odpadów w } \\
\text { Suchej Beskidzkiej) - ul. Wadowicka }\end{array}$ & Natural gas \\
\hline 8. & Machaczka Bakery (Piekarnia Machaczka) - ul. Rynek & Fuel oil \\
\hline 9. & Wągiel Bakery (Piekarnia Wągiel) - ul. Role & $\begin{array}{l}\text { Fuel oil / } \\
\text { wood/ coal }\end{array}$ \\
\hline 10. & Kuracjusz Beskidzki - ul. Tarnowskiego & Coal \\
\hline 11. & TAURON Power Company (Zakład energetyczny)- ul. Przemysłowa & $\begin{array}{l}\text { Electrical } \\
\text { energy }\end{array}$ \\
\hline 12. & Kasper Suski Hotel and Restaurant- ul. Zamkowa & Natural gas \\
\hline 13. & Capri Wedding House (Dom Weselny Capri) - ul. Spółdzielców & Natural gas \\
\hline 14. & Hotel Montis - ul. Spółdzielców & Natural gas \\
\hline 15. & Biedronka - ul. Mickiewicza & Natural gas \\
\hline 16. & Tesco Polska Ltd. - ul. Handlowa & Natural gas \\
\hline 17. & Intermarche - ul. Mickiewicza & Natural gas \\
\hline 18. & Bricomarche - ul. Mickiewicza & Natural gas \\
\hline 19. & $\begin{array}{l}\text { Complex of shopping facilities in the form of } 55 \text { terraced buildings (kompleks obiektów handlowych w } \\
\text { zabudowie szeregowej } 55 \text { budynków) - ul. Mickiewicza }\end{array}$ & Natural gas \\
\hline 20. & Black Red White - ul. Zamkowa & Natural gas \\
\hline 21. & Trading Company (Firma handlowa) „Cytrus D. Czarnecka J. Czarnecki Sp.J.” - & Natural gas \\
\hline 22. & Trading Company (Firma handlowa) EWJAN - ul. Zamkowa & Natural gas \\
\hline 23. & Robert Lichosyt Construction company (Firma Budowlana Robert Lichosyt - ul. Przemysłowa) & Natural gas \\
\hline
\end{tabular}

Source: Own study based on the data from the Town Hall of Sucha Beskidzka

Table 10. Number of boilers replaced between 2014 and 2016 as part of subsidies provided by the Municipality

\begin{tabular}{|l|l|c|c|c|}
\hline \multirow{3}{*}{ Single-family buildings } & New energy source & 2014 & 2015 & 2016 \\
\cline { 2 - 4 } & eco-coal & 4 & 46 & 48 \\
\cline { 2 - 4 } & gas & 2 & 7 & 17 \\
\cline { 2 - 4 } & biomas & - & 3 & 5 \\
\hline \multirow{2}{*}{ Public buildings } & gas & - & 1 & - \\
\hline & fuel oil & - & - & - \\
\hline Buildings where business is carried out & eco-coal & 2 & 6 & 7 \\
\hline \multirow{2}{*}{$\begin{array}{l}\text { Multi-family buildings } \\
\text { (15 blocks of flats) }\end{array}$} & number of blocks of flats & 90 & 174 & 162 \\
\cline { 2 - 4 } & number of households in the blocks & 195 & 419 & 533 \\
\cline { 2 - 4 } & withdrawn tile/coal stoves as above & 195 & - \\
\hline
\end{tabular}

Source: Own study based on the data from the Town Hall of Sucha Beskidzka

Table 11. Ecological effect resulting from replacing coal as heat source with gas (reduction)

\begin{tabular}{|c|c|c|c|c|c|}
\hline \multirow{2}{*}{ Year } & Total particulate matter & $\mathrm{SO}_{2}$ & $\mathrm{NOx}$ & $\mathrm{CO}$ & $\mathrm{CO}_{2}$ \\
\cline { 2 - 6 } & \multicolumn{5}{|c|}{$\mathrm{kg} / \mathrm{rok}$} \\
\hline 2014 & 2549.5 & 4100.0 & 127.3 & 12475.8 & 180860.0 \\
\hline 2015 & 6136.1 & 9054.3 & 394.5 & 29711.5 & 449055.0 \\
\hline 2016 & 5257.8 & 8456.0 & 392.9 & 449055.0 & 374204.3 \\
\hline
\end{tabular}

Source: Own study based on the data from the Town Hall of Sucha Beskidzka 
of the City Guard collect samples of ash for research at the Cracow University of Technology, with which the Sucha Beskidzka Municipality signed a cooperation agreement in 2011. If incineration of prohibited substances is confirmed, maximum fines are imposed on the building proprietors.

- The system of municipal waste collection in Sucha Beskidzka contributes to the detection of perpetrators of air pollution. Bar codes and readers are used. Wastes are controlled upon collection which allows for precise determination of weight, number, type and degree of segregation.

- The municipality of Sucha Beskidzka participates in the Life Program, and as part of it, an eco-adviser was employed, who gives advice on coal boilers replacement, participates in inspections, conducts environmental education and organises trainings in this area.

- Implemented air protection actions bring the intended effects and will be continued by the local government in the coming years.

- Sucha Beskidzka is one of the two cities in the Małopolskie province which fully implemented the Air Protection Program planned for the years 2013-2015. Between 2014 and 2016, as many as 103 buildings underwent thermo-modernisation. In 2016 RES (solar installations) were installed in 402 detached houses. In the period 2014-2016, 1055 coal boilers were dismantled and replaced with gas boilers or class 5 boilers. In 2016, only 423 applications for the replacement of class 5 or gas boilers were submitted.

- As a result of the replacement of coal as heat source with gas, the reduction of $13943.4 \mathrm{~kg} /$ year of total particulate matter was achieved in the municipality in the years 2014-2016.

- The Sucha Beskidzka Municipality is exemplary in the realisation of the LERP Program and should strive for the further development of low carbon economy.

\section{REFERENCES}

1. Gostomczyk, W.2014. Low carbon economy. Conditions and Challenges: Does Poland shape a modern low carbon economy (in Polish), pp. 69-98.

2. Jankiewicz, S.2014. Low carbon economy. Conditions and Challenges: The importance of developing low carbon economy for the labour market in Poland (in Polish), pp. 112-124.

3. Kaczmarczyk M., et al. 2015. Low emission: from reasons for appearing to the means of elimination (in Polish). GLOBEnergia Publishing House, Krakow.

4. Lewińska J., K. Zgud, J.Baścik, W. Wiatrak. 1990. The climate of urbanised areas (in Polish). Institute of Spatial and Municipal Economy. Warsaw, pp. 32-35.

5. Local Development Plan of the Municipality of Sucha Beskidzka for the years 2004-2013 (in Polish), pp.13-39.

6. Air Protection Program for the Malopolska province. 2017. Małopolska in a healthy atmosphere (in Polish), p. 11.

7. Air Protection Program for the Malopolska province. 2017. Małopolska in a healthy atmosphere (in Polish). Justification, pp. 143-145.

8. Air Protection Program for the Malopolska province. 2017. Małopolska in a healthy atmosphere (in Polish). Justification, p. 260.

9. Air Protection Program for the Malopolska province. 2017. Małopolska in a healthy atmosphere (in Polish). Justification, p. 32.

10. Air Protection Program for the Malopolska province. 2017. Małopolska in a healthy atmosphere (in Polish). Justification, p. 11.

11. Low Emission Restriction Program. Municipality of Sucha Beskidzka 2014 (in Polish), pp. 15-30.

12. Report 2011: Transformation towards low carbon economy in Poland. The World Bank, Department of Poverty Reduction and Economic Management. Europe and Central Asia Region (in Polish), pp. 7-10.

13. Report on the state of the environment in the Malopolska province in the years 2013-2015 (in Polish). Krakow 2016. Provincial Inspectorate for Environmental Protection in Krakow, p. 8.

14. Skrzypski J., Ż. Papiernik 2006. Bioclimate changes of cities (taking the city of Łódź as an example) (in Polish), pp. 34-36.

15. Study of conditions and directions of spatial development of the city of Sucha Beskidzka. Part I. Conditions (in Polish). Sucha Beskidzka 2016, p. 56.

16. www.google.pl 